\title{
PENGARUH PENGGUNAAN MULTIMEDIA INTERAKTIF TERHADAP PEMAHAMAN KONSEP DALAM PEMBELAJARAN MATEMATIKA DI MTS DARUL ULUM MUHAMMADIYAH GALUR
}

\author{
Erna Setyowati ${ }^{1}$, Ika Septi Hidayati ${ }^{2}$, Toto Hermawan ${ }^{3}$ \\ Pendidikan matematika Universitas Cokroaminoto Yogyakarta
}

\begin{abstract}
Abstrak
Pada saat pandemic Covid-19 ini semua pembelajaran dilakukan secara daring atau pembelajaran online sedangkan sekolah dan siswa harus tetap mengikuti kurikulum yang ada pada sekolah mereka, yang tentunya tidak semua pelajaran mereka senangi. Pelajaran matematika salah satu pelajaran yang selalu menjadi momok bagi siswa, terlepas dari mereka yang menyenangi matematika. Alasannyapun bermacam-macam, ada yang mengatakan pelajarannya sulit dimengerti, siswa yang tidak tertarik mempelajari matematika, gurunya membosankan, dan lain-lain. Sehingga banyak orang tua siswa yang memberikan les tambahan pada anak-anak mereka dengan menyewa tenaga pengajar matematika, dengan harapan anak- anak mereka cerdas matematika. Penelitian ini bertujuan untuk mengkaji pengaruh penggunaan multimedia interaktif animasi terhadap pemahaman konsep pemahaman konsep matematis siswa. Populasi penelitian ini adalah siswa kelas VII MTs Darul Ulum Muhammadiyah Galur semester genap tahun pelajaran 2019/2020. Dari lima kelas yang ada diambil dua kelas secara acak sebagai sampel dengan satu kelas sebagai kelas eksperimen dan satu kelas sebagai kelas kontrol. Penelitian ini menggunakan the randomized pretest-posttest control group design. Data penelitian diperoleh melalui tes berbentuk uraian pada materi Persegi Panjang dan Persegi. Hasil penelitian menunjukkan adanya perbedaan pemahaman konsep matematis pada siswa yang menggunakan multimedia interaktif animasi lebih tinggi daripada pemahaman konsep matematis siswa yang mengikuti pembelajaran konvensional, dan Ada pengaruh positif dan signifikan penggunaan media interaktif animasi terhadap Pemahaman Konsep Matematika Siswa Kelas VII MTs Darul Ulum Muhammadiyah Galur Tahun Ajaran 2019/2020. Hal ini ditunjukkan oleh $\mathrm{t}^{\text {hitung }}=2,27$ sedangkan $\mathrm{t}^{\text {tabel }}=2.060$ pada taraf signifikan $5 \%$ dan ${ }^{d b} 22-2=20$. Sehingga diperoleh, koefisien determinannya sebesar 20.47 dengan persamaan regresi $=13,828+0,035 \mathrm{X}$ siswa sebesar $20 \%$ dan selebihnya yang $80 \%$ dipengaruhi oleh faktor lain
\end{abstract}

Kata kunci: multimedia interaktif, animasi matematika, pemahaman konsep matematis, persegi dan persegi panjang 


\section{Pendahuluan}

Matematika adalah pelajaran yang tak pernah luput dari perhatian kita semua baik itu bagi seorang pendidik maupun siswa, karena matematika merupakan mata pelajaran yang sangat penting untuk dipelajari, dikuasai dan dipahami oleh seluruh siswa serta matematika juga selalu ada dalam setiap tahapan pendidikan di sekolah. Pembelajaran matematika adalah pembelajaran mengenai angka-angka, pengoperasian angka-angka dan pengaplikasian dari sekian banyak rumus-rumus yang kemudian dapat disajikan sacara runtun, tepat dan benar. Penguasaan matematika bagi siswa sangatlah penting, baik untuk menunjang keberhasilannya dalam ilmu pendidikan maupun dikehidupannya sehari-hari.

Peranan penguasaan matematika sangat diperlukan dalam menunjang keberhasilan siswa pada dunia pendidikan maupun dibidang pembangunan nantinya. Hal ini karena penguasaan mata pelajaran matematika merupakan salah satu syarat yang penting bagi siswa untuk memahami serta mempelajari mata pelajaran lainnya. Selain itu matematika juga merupakan pelajaran yang penting dan akan sering digunakan dalam mata pelajaran-mata pelajaran yang lain, baik pada tahapan yang sama maupun pada tahapan pendidikan yang lebih tinggi lagi nantinya.

Pada saat pandemic Covid-19 ini semua pembelajaran dilakukan secara daring atau pembelajaran online sedangkan sekolah dan siswa harus tetap mengikuti kurikulum yang ada pada sekolah mereka, yang tentunya tidak semua pelajaran mereka senangi. Pelajaran matematika salah satu pelajaran yang selalu menjadi momok bagi siswa, terlepas dari mereka yang menyenangi matematika. Alasannyapun bermacam-macam, ada yang mengatakan pelajarannya sulit dimengerti, siswa yang tidak tertarik mempelajari matematika, gurunya membosankan, dan lain-lain. Sehingga banyak orang tua siswa yang memberikan les tambahan pada anak-anak mereka dengan menyewa tenaga pengajar matematika, dengan harapan anak- anak mereka cerdas matematika.

Seiring majunya teknologi muncul berbagai media pembelajaran baru, salah satunya yaitu media interaktif animasi. Media interaktif animasi merupakan sistem pembelajaran berbasis multimedia karena media ini dapat menyajikan informasi yang dapat dilihat, didengar, dan dilakukan sekaligus. Computer Technology Research (CTR) menyatakan bahwa orang hanya mampu mengingat $20 \%$ dari yang dilihat dan $30 \%$ dari yang didengar. Tetapi orang dapat mengingat $50 \%$ dari yang dilihat dan didengar dan $80 \%$ dari yang dilihat, didengar dan dilakukan sekaligus. Berdasarkan dari hal tersebut maka dengan penggunaan media interaktif animasi siswa dapat mengingat materi $80 \%$, karena siswa mampu mendapatkan informasi atau materi pembelajaran dari media tersebut dengan melihat, mendengar, dan kedua hal tersebut sekaligus. Selain itu siswa juga akan dapat mengoperasikannya langsung sehingga siswa menjadi lebih interaktif dan pada media ini terdapat animasi yang merupakan bentuk visual bergerak yang dapat dimanfaatkan untuk menyampaikan pesan agar lebih menarik dan mudah dipahami. Dengan hal itu maka media tersebut sangat efektif untuk menjadi media yang lengkap 
dalam proses yang dapat menumbuhkan pemahaman konsep siswa dalam belajar khususnya belajar matematika.

Berdasarkan hasil observasi dan wawancara pada penelitian pendahuluan dengan salah satu pendidik di MTs Darul Ulum Muhammadiyah Galur, diperoleh informasi bahwa pemahaman konsep siswa khususnya dalam belajar matematika cukup rendah, cara mengajar pada saat pandemi Covid-19 ini pendidik cenderung menjelaskan konsep secara informatif, pendidik sendiri juga kurang variatif dalam menggunakan media pembelajaran. Sedangkan pembelajaran matematika itu sendiri bertujuan agar siswa dapat memahami konsep-konsep matematika yang abstrak, mampu memecahkan masalah berkaitan dengan operasi hitung, dan dapat mengkomunikasikan gagasan dengan simbol. Oleh karena itu kualitas pembelajaran matematika di MTs Darul Ulum Muhammadiyah Galur harus ditingkatkan. Melalui wawancara dengan pendidik di MTs Darul Ulum Muhammadiyah Galur diketahui bahwa beberapa siswa masih menganggap pelajaran matematika sebagai suatu mata pelajaran dengan materi yang sulit dimengerti dan membosankan sehingga siswa menjadi malas dalam belajar matematika serta cenderung pasif dan tidak semangat saat pembelajaran. Kondisi tersebut membuat pembelajaran menjadi kurang bermakna sehingga dapat mengurangi pemahaman konsep siswa dalam belajar matematika yang akan berdampak pada nilai akhir siswa. Kurang variatif dan optimalnya media pembelajaran yang digunakan juga menjadi penyebab rendahnya pemahaman konsep matematika di MTs Darul Ulum Muhammadiyah Galur

\section{Kajian Teori}

\section{Pemahaman Konsep Matematis}

Pemahaman merupakan kemampuan berpikir untuk mengetahui tentang sesuatu hal serta dapat melihatnya dari beberapa segi. Kemampuan berpikir tersebut meliputi kemampuan untuk membedakan, menjelaskan, memperkirakan, menafsirkan, memberikan contoh, menghubungkan, dan mendemonstrasikan.

Ranah kognitif dalam taksonomi Bloom terdiri dari enam jenis perilaku yaitu:

1) Tingkat pengetahuan, yaitu kemampuan seseorang dalam menghafal, memgingat kembali, atau mengulang kembali pengetahuan yang pernah diterimanya.

2) Tingkat pemahaman, diartikan sebagai kemampuan seseorang dalam mengartikan, menafsirkan, menerjemahkan, atau menyatakan sesuatu dengan caranya sendiri tentang pengetahuan yang pernah diterimanya.

3) Tingkat penerapan, diartikan sebagai kemampuan seseorang dalam menggunakan pengetahuan untuk memecahkan berbagai masalah yang timbul dalam kehidupan sehari-hari. 
4) Tingkat analisis, yaitu sebagai kemampuan seseorang dalam merinci, dan membandingkan data yang rumit serta mengklasifikasikan menjadi beberapa kategori denggan tujuan agar dapat menghubungkan dengan data-data yang lain.

5) Tingkat sintesis, yakni sebagai kemampuan seseorang dalam mengaitkan dan menyatukan berbagai elemen dan unsur pengetahuan yang ada sehingga terbentuk pola baru yang lebih menyeluruh

6) Tingkat evaluasi, yakni sebagai kemampuan seseorang dalam membuat perkiraan atau keputusan yang tepat berdasarkan kriteria atau pengetahuan yang dimilki.

Pada aspek pemahaman ialah kemampuan yang mendapat penekanan dalam proses belajar-mengajar. Peserta didik dituntut memahami atau mengerti apa yang diajarkan, mengetahui apa yang sedang dikomunikasikan dan dapat memanfaatkan isinya tanpa keharusan menghubungkannya dengan hal-hal lain. Bentuk soal yang sering digunakan untuk mengukur kemampun ini adalah pilihan ganda atau uraian. Kemampuan pemahaman dapat dijabarkan menjadi tiga, yaitu :

1) Menerjemahkan (translation), yakni bukan saja pengalihan arti dari bahasa yang satu kedalam bahasa yang lain. Dapat juga dari konsepsi abstrak menjadi suatu model, yaitu model simbolik untuk mempermudah orang mempelajarinya. Kata kerja operasional yang digunakan untuk merumuskan TIK dan mengukur kemampuan menerjemahkan ini adalah menerjemahkan, mengubah, mengilustrasikan.

2) Menginterprestasi (interprelation), yakni kemampuan untuk mengenal dan memahami.

3) Mengekstrapolasi (extrapolation), yakni kesanggupan melihat dibalik yang tertulis, tersirat dan tersurat, meramalkan sesuatu, dan memperluas wawasan. Ia menuntut kemampuan intelektual yang lebih tinggi. Kata kerja operasional yang dapat dipakai untuk mengukur kemampuan ini adalah memperhitungkan, memperkirakan, menduga, menyimpulkan, meramal, membedakan, menentukan, mengisi dan menarik kesimpulan.

Kata kerja operasionl dalam Tujuan Instruksional Khusus (TIK) untuk jenjang pemahaman meurut Bloom, diantaranya: "membedakan, mengubah, mempersiapkan, menyajikan, mengatur, menginterpretasikan, menjelaskan, mendemonstrasikan, memberi contoh, memperkirakan, menentukan, mengambil 
kesimpulan. Sedangkan konsep adalah suatu ide abstrak yang memungkinkan seseorang untuk mengklasifikasi suatu objek dan menerangkan apakah objek tersebut merupakan contoh atau bukan contoh dari ide abstrak tersebut. Konsep merupakan buah pemikiran seseorang atau sekelompok orang yang dinyatakan dalam definisi sehingga melahirkan produk pengetahuan meliputi prinsip-prinsip, hukum, dan teori”. Suatu konsep terbentuk dalam pikiran individu melalui proses mengenal dan memahami ciri-ciri konsep atas dasar contoh dan non-contoh. Untuk membantu peserta didik berhasil dalam belajar konsep, dalam kegiatan pembelajaran guru hendaknya melaksanakan hal-hal berikut :

a) Menyajikan konsep yang akan dipelajari baik secara lisan maupun tertulis. Pernyataan tentang konsep ini akan masuk kedalam sistem ingatan. Peserta didik mampu mengungkapkan kembali konsep tersebut dari sistem ingatannya.

b) Menyajikan contoh ketika membahas yang harus dikuasai peserta didik. Dengan adanya contoh dan non-contoh ini, penguasaan peserta didik terhadap konsep yang dipelajari akan lebi cepat dibandingkan apabila guru tidak memberikan contoh dan non-contoh.

c) Apabila peserta didik telah menguasai konsep yang sedang dipelajari, guru perlu memberikan penguatan terhadap peserta didik. Penguatan ini diberikan segera setelah peserta didik menunjukkan kemampuannya. Kesegeraan pemberian penguatan ini berpengaruhi terhadap kecepatan peserta didik menguasai konsep yang dipelajari.

Menurut Fadjar Shadiq pemahaman konsep merupakan kompetensi yang ditunjukkan peserta didik dalam memahami konsep dan dalam melakukan prosedur (algoritma) secara luwes, akurat, efisien, dan tepat. Dan dari pengertian pemahaman dan konsep di atas maka penulis menyimpulkan bahwa pemahaman konsep adalah kemampuan peserta didik yang berupa penguasaan sejumlah materi pelajaran, dimana peserta didik tidak sekedar mengetahui atau mengingat sejumlah konsep yang dipelajaari, tetapi mampu mengungkapkan kembali dalam bentuk lain yang mudah dimengerti, memberikan interprestasi data dan mampu mengaplikasikan konsep yang sesuai dengan struktur kognitif yang dimilikinya.

Menurut Sri Wardhani "memahami konsep matematis ialah menjelaskan keterkaitan antar kosep dan mengaplikasikan konsep atau algoritma, secara luwes, 
akurat, efisien, dan tepat dalam pemecahan masalah”. Jadi, pemahaman konsep matematis merupakan kompetensi yang ditunjukkan peserta didik dalam memahami konsep dan dalam melakukan prosedur (algoritma) secara luwes, akurat, efisien, dan tepat. Kemampuan pemahaman konsep matematis adalah penyerapan makna dari materi matematika yang sedang dipelajari.

\section{Media Pembelajaran}

Arsyad (2007: 3) mengatakan bahwa kata media berasal dari bahasa latin medius yang secara harfiah berarti tengah, perantara atau pengantar. Sedangkan menurut Sadiman dkk (2014: 7) menjelaskan "media pembelajaran adalah segala sesuatu yang dapat digunakan untuk menyalurkan pesan dari pengirim ke penerima pesan sehingga dapat merangsang pikiran, perasaan, perhatian, dan minat peserta didik sehingga proses belajar dapat terjadi”.

Berdasarkan beberapa pendapat di atas dapat disimpulkan bahwa media pembelajaran adalah suatu bahan, alat atau metode yang digunakan pendidik sebagai perantara komunikasi/interaksi antara pendidik dan peserta didik dalam kegiatan pembelajaran untuk mencapai tujuan pembelajaran dan menyajikan materi pelajaran secara kongkrit sehingga peserta didik mudah menerima dan mencerna pelajaran yang diberikan oleh pendidik yang memberikan pengaruh akan ketertarikan saat belajar sehingga peserta didik memiliki minat akan belajar

\section{Multimedia Interaktif Animasi}

Menurut Daryanto (2013: 51) "multimedia interaktif adalah suatu multimedia yang dilengkapi dengan alat pengontrol yang dapat dioperasikan oleh pengguna, sehingga pengguna dapat memilih apa saja yang dikehendaki untuk proses selanjutnya". Kemudian menurut Munir (2013: 110) "multimedia interaktif adalah suatu tampilan multimedia yang di rancang oleh designer agar tampilannya memenuhi fungsi menginformasikan pesan dan memiliki interaktifitas kepada penggunanya (user)". Berikut karakteristik multimedia interaktif dalam pembelajaran menurut Munir (2013: 115) yaitu:

a) Memiliki lebih dari satu media yang konvergen, misalnya menggabungkan unsur audio dan visual

b) Bersifat interaktif, dalam pengertian memiliki kemampuan untuk mengakomodasi respon pengguna,

c) Bersifat mandiri dalam pengertian memberi kemudahan dan kelengkapan isi sedemikian rupa sehingga pengguna bisa menggunakan tanpa bimbingan orang lain. 
Media interaktif ini dirancang untuk melibatkan respon pemakai secara aktif dan memberikan hubungan atau aksi yang dapat memberikan pengalaman belajar langsung. Menurut Harto (2008: 3) bahwa:

"Pengertian interaktif terkait dengan komunikasi dua arah atau lebih dari komponenkomponen komunikasi. Komunikasi dalam media interaktif (berbasis komputer) merupakan hubungan manusia (sebagai user/pengguna produk) dengan komputer (software/aplikasi/produk dalam format file tertentu, biasanya dalam bentuk CD). Dengan demikian, produk/CD/Aplikasi yang diharapkan memiliki hubungan dua arah/timbal balik antara software/aplikasi dengan user"

Hal tersebut sejalan dengan Anitah (2009: 59) yang berpendapat bahwa media interaktif adalah media yang meminta pembelajar mempratekkan keterampilan dan menerima balikkan. Selanjutnya Seels dan Glasgow dalam Arsyad (2006: 36) mengemukakan bahwa:

"Media interaktif merupakan sistem media penyampaian yang menyajikan materi video rekaman dengan pengendalian komputer kepada penonton (peserta didik) yang tidak hanya mendengar dan melihat video dan suara, tetapi juga memberikan respon yang aktif dan respon itu yang menentukan kecepatan dan sekuensi penyajian. Media interaktif memiliki unsur audio-visual (termasuk animasi) dan disebut interaktif karena media ini dirancang dengan melibatkan respon pemakai secara aktif."

Menurut Suryani dkk (2018: 201) media interaktif adalah "media yang memungkinkan peserta didik berinteraksi dengan media tersebut dengan memperaktikkan keterampilan yang dimiliki dan menerima feedback terhadap materi yang disajikan". Dimana partisipasi peserta didik akan lebih besar sehingga mampu mempelajari materi mendalam yang sesuai dengan paradigma konstrutivistik, mendukung individualisasi terhadap gaya belajar setiap peserta didik, fleksibilitas yang lebih memadai sehingga lebih luwes terhadap kondisi peserta didik, mampu menyimulasikan suatu objek yang tidak bisa dihadirkan di dalam kelas.

Berdasarkan beberapa pendapat di atas penulis menyimpulkan bahwa media interaktif merupakan alat perantara yang dirancang dengan pemanfaatan komputer menggunakan unsur seperti suara (audio), gambar (visual) dan teks untuk menyampaikan suatu pesan yang dapat melibatkan pemakai secara keseluruhan baik dalam menerima atau memberikan balikan yang dikendalikan dengan sistem yang sudah dirancang khusus dan memberikan respon peserta didik yang aktif. Apabila pengguna mendapatkan keleluasaan dalam mengontrol media tersebut, maka hal ini disebut media interaktif. 


\section{Pembahasan}

Hasil analisis data menunjukkan bahwa penggunaan multimedia interaktif animasi pada kelompok eksperimen mampu memberikan pengaruh yang lebih besar terhadap peningkatan pemahaman belajar siswa dari pretest ke posttest bila dibandingkan dengan kelompok kontrol. Hal itu terjadi karena penggunaan multimedia interaktif animasi dapat memberikan pembelajaran bermakna sehingga membuat pemahaman siswa lebih meningkat. Hal itu sejalan dengan hasil sebuah penelitian yang dilakukan oleh Animesh K. Mohapatra dan Reena Mohapatra dengan judul effect of animation in reconstructing students' knowledge of cell division (mitosis)9 yang menunjukkan bahwa penggunaan media animasi dapat memberikan pembelajaran bermakna.

Lebih besarnya penguasaan konsep kelompok eksperimen juga disebabkan karena dalam proses pembelajaran dengan menggunakan Multimedia interaktif animasi, konsep matematis yang kompleks dapat lebih mudah dijelaskan pada siswa dengan cara analogi maupun dengan mengkonkretkan proses-proses yang abstrak sehingga membantu siswa dalam hal visualisasi yang kuat.

Hal tersebut sejalan dengan sebuah penelitian yang dilakukan oleh Yosi Rotbain, Gili Marbach-Ad d dan Ruth Stavy dengan judul using a computer animation to teach high school molecular biology(Yosi Rotbain, Gili Marbach-Ad d dan Ruth Stavy, Usinng A Computer Animation To Teach High School Molecular Biology. J Sci Educ Technol (2008) 17:49-58. DOI 10.1007/s10956-007-9080-4 ) yang menyatakan bahwa media animasi mampu membantu pemahaman siswa dalam hal visualisasi, penggambaran konsep abstrak, serta memberikan dorongan dalam hal minat belajar.

Dalam situasi dan kondisi pandemic Covid-19 proses belajar-mengajar dilakukan secara daring dan di MTs Darul Ulum Muhammadiyah Galur melakukan proses pembelajaran tersebut dengan memanfaatkan media WhatsApp untuk berkomunikasi dengan siswa.

Pada pertemuan pertama kelompok eksperimen, peneliti sebagai guru memperkenalkan diri dengan siswa dan menyanyakan keadaan siswa, lalu diikuti dengan menjelakan maksud dan tujuan pembelajaran yang akan dilakukan selama 2 pertemuan ini membahas materi persegi Panjang dan persegi menggunakan multimedia interaktif tapi sebelum masuk ke materi dan media pembelajaran siswa diingatkan kembali mengenai materi persegi panjang dan persegi yang pernah diajarkan sewaktu SD melalui soal 
pemahaman konsep pretest juga sebagai acuan guru melihat pemahaman konsep matematika siswa kelas eksperimen.

Setelah mengingat kembali materi persegi Panjang dan persegi guru memberikan penjelasan tata cara penggunaan multimedia interaktif animasi via desktop dan cara/ petunjuk untuk menginstal multimedia interaktif pada ponsel siswa berupa mobileapps, kemudian siswa diminta untuk mencoba menginstall mobileapps yang telah diberikan guru dengan petunjuk yang telah dijelaskan. Diakhir pembelajaran daring pada pertemuan pertama guru membuka sesi tanya jawab terkait permasalahan cara menginstal dan menggunakan multimedia interaktif yang telah diberikan dan memberikan sedikit ulasan mengenai konsep persegi Panjang dan persegi serta meminta siswa untuk belajar secara mandiri materi, contoh soal dan mencoba latihan soak persegi Panjang dan persegi menggunakan multimedia interaktif untuk dibahas dipertemuan selanjutnya. Lalu dipertemuan kedua diadakan tanya jawab untuk menanggapi apakah masih ada kesulitan dalam mengakses media pembelajaran tersebut baik via desktop ataupun mobileapps serta mengadakan tanya jawab untuk menanggapi dan memperkuat pemahaman konsep siswa, respon siswa pada sesi tersebut siswa menyebutkan bahwa mereka belum pernah mendapatkan materi pelajaran menggunakan mobileapps seperti ini dan banyak siswa yang merasa senang belajar menggunakan mobileapps ini. Setelah siswa merasa sudah cukup dalam bertanya lalu pada pertemuan ketiga diadakan tes akhir atau posttest.

Pada pertemuan pertama kelompok kontrol, peneliti memberikan sedikit ulasan mengenai konsep persegi panjang dan persegi dengan mengarahkan ke buku paket pegangan siswa kelas VII, kemudian siswa diarahkan untuk belajar mandiri konsep/materi persegi dan persegi panjang menggunakan buku paket tersebut tersebut. Lalu dipertemuan kedua diadakan tanya jawab untuk menanggapi dan memperkuat pemahaman konep siswa pada materi persegi panjang dan persegi, setelah itu siswa diminta untuk mengerjakan soal posttest.

Berkaitan dengan multimedia interaktif animasi, mengandung visual animasi sekaligus menarik perhatian siswa dalam belajar. menurut teori tingkat pengolahan, dalam faktor yang meningkatkan daya ingat jangka panjang, disebutkan bahwa makin banyak perhatian yang diberikan pada bagian-bagian tertentu, makin banyak pengolahan mental yang dilakukan atas bagian tertentu, maka makin besar pula kemungkinan bagian-bagian tertentu tersebut diingat. (Robert E. Slavin, Psikologi Pendidikan, (Jakarta: PT indeks, 2008), h.231.) 
Peningkatan siswa didukung juga oleh hasil analisis lembar observasi dan angket. Berdasarkan hasil observasi terhadap guru mengenai keterlaksanaan kegiatan guru dalam melakukan tahap pembelajaran, menunjukkan bahwa pengajar telah melakukan tahapan kegiatan pembelajaran dengan baik. Berdasarkan hasil observasi yang dihubungkan dengan hasil belajar siswa, terlihat adanya perubahan tingkat pemahaman konsep yang lebih baik. Hal ini terlihat dari perolehan data posttest yang secara positif signifikan meningkat.

Berdasarkan perhitungan angket, dari keempat prinsip pemilihan media, secara keseluruhan mendapatkan kategori yang tinggi. Baik pada prinsip perhatisn, keterkaitan keyakinan dan kepuasan dari hasil perhitungan rata rata yang didapat, menunjukkan bahwa sebagian besar siswa menyatakan bahwa multimedia interaktif animasi yang disuguhkan merupakan media belajar yang mendapatkan perhatian, ketkaitan, keyakinan dan kepuasan, sesuai dengan bahan dan tujuan pembelajaran sehingga dapat membantu memahami konsep yang diajarkan.

Multimedia interaktif animasi sebagai media pembelajaran memiliki banyak kelebihan. Disamping mampu mengkonkretkan konsep yang abstrak, dapat dibuka ulang jika dibutuhkan, multimedia interaktif juga memiliki nilai hiburan tersendiri bagi peserta didik. Sehingga siswa merasa tertarik dan materi yang disampaikan dapat dipahami dengan baik oleh siswa. Maka, berdasarkan olah data dan pembahasan yang didapat, disimpulkan bahwa penggunaan multimedia interaktif animasi berpengaruh terhadap pemahaman konsep matematika siswa pada konsep persegi Panjang dan persegi.

Dan dari perhitungan koefisien determinan diperoleh disimpulkan bahwa ada pengaruh positif signifikan penggunaan multimedia interaktif animasi terhadap pemahaman konsep matematika siswa sebesar $20 \%$ dan selebihnya yang $80 \%$ dipengaruhi oleh faktor lain.

\section{Kesimpulan}

1. Ada perbedaan penggunaan media interaktif animasi terhadap Pemahaman Konsep Matematika Siswa Kelas VII MTs Darul Ulum Muhammadiyah Galur Tahun Ajaran 2019/2020 dapat dilihat dari hasil perbedaan nilai rata rata dan variansi posttes kelas experiment dan kontol

2. Ada pengaruh positif dan signifikan penggunaan media interaktif animasi terhadap Pemahaman Konsep Matematika Siswa Kelas VII MTs Darul Ulum Muhammadiyah Galur Tahun Ajaran 2019/2020. Hal ini ditunjukkan oleh 
$\mathrm{t}=2,27$ sedangkan $\mathrm{t}=2.060$ pada taraf signifikan $5 \%$ dan $22-2=20$. Sehingga diperoleh, koefisien determinannya sebesar 20.47 dengan persamaan regresi $=$ $13,828+0,035 \mathrm{X}$

\section{Daftar Pustaka}

Anitah, Sri. 2009. Media Pembelajaran. UNS Press, Surakarta.

Arikunto, Suharsimi. 2014. Prosedur Penelitian: Suatu Pendekatan Praktik. Rineka Cipta, Jakarta.

Asyhar, Rayandra. 2012. Kreatif Mengembangkan Media Pembelajaran. Referensi Jakarta, Jakarta.

Arsyad, Azhar. 2007. Media Pembelajaran. PT Raja Grafindo Persada, Jakarta. Budiningsih, Asri. 2005. Belajar dan Pembelajaran. PT Rineka Cipta, Jakarta. Baharudin. 2009. Psikologi Pendidikan Refleksi Teoritis Terhadap Fenomena. Ar-Ruzz Media, Yogyakarta.

Dalyono, Muhammad. 2001. Psikologi Pendidikan. PT Rineka Cipta, Jakarta.

Daryanto. 2013. Media pembelajaran. Gava Media, Yogyakarta.

Farida, Hanik. 2014. Pengaruh Media Interaktif Animasi Terhadap Minat Belajar Pada Mata Pelajaran IPA Siswa Kelas IV SDIT Mta Matesih Tahun Ajaran 2013/2014. Skripsi, Universitas Muhammadiyah Surakarta. http://eprints.ums.ac.id/29532/.

Frey, Barbara dan Sutton, Jane. 2010. A Model for Developing Multimedia Learning Projects. Journal of Online Learning and Teaching. Vol.6 No.2, June 491-507. http://jolt.merlot.org/vol6no2/frey_0610.pdf.

Hakim, Arif Rahman. 2016. Pengaruh Penggunaan Multimedia Interaktif Dalam Pembelajaran Matematika Untuk Meningkatkan Hasil Belajar Siswa SD. http://ejournal.upi.edu/index.php/eduhumaniora/article/view/2827.

Jatmiko, Dani. 2015. Pengaruh penggunaan multimedia pembelajaran interaktif mata pelajaran pndidikan agama islam terhadap hasil belajar siswa kelas IV sekolah dasar negeri sebomenggalan purworejo. Universitas Negeri Yogyakarta. https://eprints.uny.ac.id/28101/1/Dani\%20Jatmiko_08105241011.pdf.

Milovanović, Marina et al. 2013. Aplication of Interactive Multimedia Tools in Teaching Mathematics-Examples of Lessons From Geometry. Turkish Online Jurnal of Educational Technology. January 2013, Vol.12, issue 1: 19-31. www.tojet.net.

Margono. 2010. Metodologi Penelitian Pendidikan. Rineka Cipta, Jakarta.

Nusir et al. 2012. Studying The Impact Of Using Multimedia Interactive Programs At 
Children Ability To Learn Basic Math Skills. Acta Didactica Napocensia.5(2):17-31.

http://dppd.ubbcluj.ro/adn/article_5_2_3.pdf.

Sadiman, Arief S dkk. 2014. Media Pendidikan Pengertian, Pengenmbangan, dan Pemanfaatannya. PT Raja Grafindo Persada, Jakarta.

Sardiman, A. M. 2007. Interaksi dan Motivasi Belajar Mengajar. PT Raja Grafindo Persada, Jakarta.

Suhartini, Dewi. 2001. Minat Siswa Terhadap Topik-Topik Terhadap Mata Pelajaran 15 Sejarah Dan Faktor-Faktor Yang Melatarbelakanginya: Studi Deskriptif Terhadap Siswa Sekolah Menengah Umum Negeri Di Kota Bogor. Tesis. Magister Pendidikan Ilmu Sosial. UPI, Bandung.

Suheri, Agus. 2006. Animasi Multimedia Pembelajaran. Jurnal Media Teknologi, Vol. 2, No. 1. Universitas Suryakencana, Cianjur.

Yunita, Liza. 2017. Pengaruh Penggunaan Media Animasi Terhadap Aktivitas dan Hasil Belajar Siswa Pada Materi Sistem Pencernaan di SMP 1 Darussalam. Universitas Islam Negeri Ar-raniry Darussalam-Banda Aceh. https://repository.ar-raniry.ac.id/504/1/skripsi\%20gabungan.pdf. 